\title{
Does the timing of aspirin administration influence its antiplatelet effect - review of literature on chronotherapy
}

\author{
Ewa Miciak-Ławicka ${ }^{1}$, Beata Begier-Krasińska ${ }^{1}$, Andrzej Tykarski $^{1}$, Zbigniew Krasiński $^{2}$ \\ ${ }^{1}$ Department and Clinic of Hypertensiology, Angiology, and Internal Medicine, Poznan University of Medical \\ Sciences, Poznan, Poland \\ ${ }^{2}$ General and Vascular Surgery Department, Poznan University of Medical Sciences, Poznan, Poland
}

Kardiochirugia i Torakochirurgia Polska 2018; 15 (2): 125-129

\begin{abstract}
This publication is a summary of the multidirectional effects of aspirin and its role in modern medicine. The history of aspirin, or acetylsalicylic acid (ASA), and its use dates back to ancient times, although the substance in its pure form has been produced and sold since 1899. Initially it was used for its antipyretic, analgesic, and anti-inflammatory effects. Over the years many other benefits associated with the administration of ASA have been revealed. The mechanism of aspirin's action was discovered thanks to the British pharmacologist and Nobel Prize winner Sir John Vane. Understanding the effects of acetylsalicylic acid, associated with the inhibition of cyclooxygenase and proinflammatory thromboxane $\mathrm{A} 2$ and with increased concentration of vasoprotective, antithrombotic prostacyclin, gave rise to the era of using small "cardiac" doses of ASA in cardiovascular diseases. In addition to the well-researched antiplatelet effect, other properties of ASA have been discovered, such as the non-COX-1 dependent improvement of endothelial function or the hypotensive effect after evening administration. According to the currently available knowledge, it is possible to speak of a pleiotropic effect of ASA and its use in the prevention of cardiovascular diseases, taking into account its anti-aggregation effect, circadian rhythms, and the principles of chronotherapy.
\end{abstract}

Key words: aspirin, platelet aggregation, chronotherapy, blood pressure.

\section{Introduction}

The natural precursor of acetylsalicylic acid, salicin, is found in willow bark and leaves. It was used as early as in the times of Hippocrates as a painkiller and antipyretic. Acetylsalicylic acid (ASA) was first synthesized in the nineteenth century from salicylic acid and introduced to the market as a drug by Bayer in 1899. In 1948 Lawrence Craven, $M D$, observed that no myocardial infarctions occurred among patients treated with ASA.

\section{Streszczenie}

Publikacja stanowi podsumowanie wielokierunkowego działania aspiryny i jej roli we współczesnej medycynie. Historia aspiryny, czyli kwasu acetylosalicylowego (ASA), i jej stosowanie sięga czasów starożytnych, choć substancja w czystej postaci produkowana i sprzedawana jest od 1899 r. Początkowo wykorzystywano jej właściwości przeciwgorączkowe, przeciwbólowe i przeciwzapalne. Z czasem odkryto wiele innych korzystnych działań ASA. Mechanizm działania aspiryny został poznany dzięki brytyjskiemu farmakologowi, laureatowi Nagrody Nobla sir Johnowi Vane'owi. Poznanie działania ASA, związane z zahamowaniem cyklooksygenazy i zwiększeniem stężenia działającej wazoprotekcyjnie, przeciwzakrzepowo prostacykliny oraz zahamowaniem prozakrzepowego tromboksanu A2, zapoczątkowało epokę stosowania małych, „,kardiologicznych" dawek ASA w chorobach układu krążenia. Obok dobrze poznanego działania przeciwpłytkowego odkrywane są inne właściwości ASA - niezależne od COX-1 działanie poprawiające funkcję śródbłonka, efekt hipotensyjny przy wieczornym podaniu. Na podstawie aktualnej wiedzy można mówić o plejotropowym działaniu ASA, jego zastosowaniu w zapobieganiu chorobom sercowo-naczyniowym, z uwzględnieniem działania antyagregacyjnego, rytmów okołodobowych i zasad chronoterapii.

Słowa kluczowe: aspiryna, agregacja płytek, chronoterapia, ciśnienie tętnicze.

Homeostasis, which may be disturbed by disease, is an important factor in the proper functioning of living organisms. This functioning is also subject to cyclical variability in the form of self-sustaining oscillations of physiological phenomena, which we refer to as biological rhythms, which are the subject matter of chronobiology - the study of biological rhythms in the functioning of organisms and the underlying mechanisms. These rhythms may have different durations, from very short (e.g., heart rhythm visible on

Address for correspondence: Ewa Miciak-Ławicka, Department and Clinic of Hypertensiology, Angiology, and Internal Medicine,

Poznan University of Medical Sciences, 112 Długa St, 61-848, Poznan, Poland, phone: +61 603969 357, fax: +61 600 595 529,

e-mail: ewka.ml@wp.pl

Received: 3.01.2018, accepted: 6.03.2018. 
ECG), significantly longer (e.g., menstrual cycle in women), to very long (e.g., annual changes in the concentration of a substance in blood). The most important and most numerous are circadian rhythms, e.g., the well-known circadian rhythms related to the variability of blood pressure, heart rate, and hemostasis. Circadian rhythm disorders may play a role in the pathogenesis of cardiovascular diseases and, just like the daily cyclicity of the risk associated with these diseases, serve as a basis for the application of the principles of chronotherapy. It is a method of adjusting the concentration and potency of a drug over time to the circadian rhythms of the biological phenomena that this drug is designed to affect. This can be done with the use of preparations with varying drug release times or by modifying the time of administration within a 24-hour period [1].

The most important factors affecting this phenomenon are chronosthesy, i.e., the circadian sensitivity of receptors to a drug in individual systems, and chronopharmacokinetics, i.e., the circadian rhythm of the processes of bioavailability, distribution, metabolism, and excretion.

The chronobiological and chronotherapeutic approach is becoming more and more widely understood, as it provides diagnostic benefits and enables more effective treatment of diseases. The classic principles for the treatment of hypertension and ischemic heart disease take circadian changes into consideration [2].

\section{Cyclicity of cardiovascular complications}

Myocardial infarctions show weekly variability, with the peak on Monday, and seasonal intensification in the winter season $[3,4]$. The results of clinical observations conducted many years ago showed that the number of acute coronary events, strokes, sudden cardiac death, symptoms of rupturing dissecting aortic aneurysms increases in the morning hours [5]. This was confirmed by an analysis of the incidence of acute coronary events, which revealed a circadian rhythm with the peak in the morning hours, between 6:00 and 10:00 [5]. Studies analyzing the occurrence of sudden death caused by arrhythmia and heart rate variability also revealed an increase in the frequency of cardiac arrests in the morning. The circadian rhythm was more pronounced in the elderly and non-hospitalized patients. Circadian heart rate variability (HRV) is one of the determinants of the risk of sudden death [5].

Blood pressure is not constant in humans over a 24hour period - it follows a circadian rhythm. Under physiological conditions, blood pressure varies by $20-30 \mathrm{~mm}$ $\mathrm{Hg}$. In active individuals blood pressure rises rapidly in the morning, immediately after waking up, and stays elevated until the afternoon. Then it slowly decreases, reaching its lowest values at night during sleep, and increases again in the morning. A normal drop in blood pressure at night should range between $10 \%$ and $20 \%$ in relation to the values measured during the day. The circadian pressure rhythm described above was discovered with the popularization of 24-hour ambulatory blood pressure monitoring (ABPM). Two parameters are important in the circadian rhythm of blood pressure, i.e., the extent of the nocturnal pressure drop in relation to the day value and the extent of the morning pressure increase [6].

Individuals with a normal pressure drop at night (by 10-20\%) are referred to as "dippers". Disorders of the circadian blood pressure profile may consist in insufficient pressure drops at night (<10\% - non-dippers), higher pressure values at night than during the day (inverse dippers), or pressure drops at night that are too pronounced $(>20 \%-$ extreme dippers) [7]. Non-dippers account for $20-40 \%$ of patients with hypertension. This phenomenon is particularly common in patients with secondary hypertension as well as in elderly and male individuals $[6,7]$.

The pathomechanism of this phenomenon is associated with increased adrenergic activity during the night hours as well as with excessive intravascular volume and salt sensitivity [8].

The reasons for the extreme dipper profile include impaired aortic compliance in hypertensive patients with decreased intravascular volume and excessive orthostatic pressure increase combined with morning a-adrenergic hyperactivation [9].

The second important parameter of a circadian blood pressure profile is the morning increase in blood pressure ( morning surge - MS). Physiologically, systolic blood pressure increases on average by $3 \mathrm{~mm} \mathrm{Hg}$ and diastolic blood pressure by $2 \mathrm{~mm} \mathrm{Hg}$ in the first 4-6 h after waking up. The reason for this excessive morning pressure increase is most likely the activation of the sympathetic nervous system. MS is defined as an increase in systolic blood pressure by $50-55 \mathrm{~mm} \mathrm{Hg}$ and diastolic pressure by $20-25 \mathrm{~mm} \mathrm{Hg}$ associated with higher cardiovascular risk [9].

\section{Circadian variability in the hemostatic system}

Hemostasis is a system of physiological processes ensuring efficient stoppage of bleeding after injury to blood vessel walls, tightness of the vascular bed, and fluidity of circulating blood. Vegetative regulation is among the various mechanisms affecting hemostasis. Under normal conditions, the systems of coagulation and fibrinolysis are in equilibrium. Changes in the circadian rhythms of the hemostatic system may lead to disorders manifesting either by excessive clotting or a tendency for bleeding [10]. Kapiotis et al. observed circadian variability in the coagulation and fibrinolytic systems when investigating factor VIIa and plasminogen activator inhibitor-1 (PAI-1) in healthy young individuals. They found a nocturnal increase in factor VII activity and a decrease during the day, while PAI-1 activity levels behaved inversely. This suggested that the observed changes may be the primary cause of the morning hypercoagulation and decreased fibrinolysis [11]. Epidemiology of prothrombotic conditions in a 24-hour context shows the highest peak in the morning hours and a smaller peak in late afternoon. Herold et al. [12] and Jaffe [13] observed that vascular endothelium is affected by circadian rhythms when producing vasoactive and anticoagulant factors. Endothelial cells release into the bloodstream vasomotor fac- 
tors affecting platelet adhesion, aggregation, and activation (prostacyclin, NO), anticoagulation factors (thrombomodulin, heparan sulphate), and fibrinolytic factors (PAI-1) [13]. Hemostasis is also affected by factors that are subject to circadian variability, i.e., peripheral resistance, blood flow, blood pressure, and heart rate $[14,15]$.

Haus observed that the number of circulating platelets is subject to circadian rhythms with a peak in the afternoon [14]. The activation and aggregation of platelets is caused by many endogenous factors, in particular: collagen, thrombin, platelet activating factor, adenosine diphosphate (ADP). Further aggregation and activation is affected by substances released from platelets: ADP, serotonin, thromboxane A2. Undar et al. observed a difference in the circadian rhythm associated with the number and activity of platelets $[15,16]$. Ex vivo measurement of platelet aggregation with monoclonal antibodies indicates that their activity is highest between 6:00 and 9:00 [15, 16]. Similarly, in vitro platelet adhesion shows the highest values in the morning hours. In vitro platelet aggregation, which is a response to the above endogenous factors, peaks in the late-night hours and soon after waking up and assuming an upright position - this is also related to the increased concentration of catecholamines at this time [14].

The key role of the fibrinolytic system in hemostasis is the dissolution of intravascular fibrin deposits and, thus, the maintenance of the fluidity of circulating blood. The highest activity of the fibrinolytic system is observed in the afternoon. A connection was also found between physical activity and increased activity of the fibrinolytic system. The activity of this system is highest in the afternoon hours [14]. The high amplitude of the circadian rhythm observed in the fibrinolytic system in the early evening leads to a reduction of blood clotting and, thus, to the possibility of bleeding, while relative hypercoagulability, i.e., decrease in the activity of the fibrinolytic system, occurs in the morning [14].

Incidents of sudden death due to cardiovascular causes, heart attacks, pulmonary embolism, ischemic strokes, or deep vein thrombosis of the lower limbs occur mainly in the morning or during the second peak in the afternoon. The weekly rhythm in the hemostatic system, including 7-day changes in the surrounding environment (activity, stress, diet), lead to an increased risk of cardiovascular events, especially at the beginning of the week. These phenomena are closely correlated with circadian rhythms in the hemostatic system. The morning increase in blood viscosity, tone of vascular smooth muscles, response to norepinephrine, blood pressure, platelet activity, and blood clotting in combination with decreased fibrinolytic activity lead to an increased risk of thromboembolic events during that time [17].

\section{Chronotherapy and the effect of aspirin}

The establishment of the mechanism of action of acetylsalicylic acid, associated with the inhibition of cyclooxygenase (COX) and increase in the concentration of vasoprotective and anticoagulant prostacyclin, as well as the discovery of prothrombotic thromboxane A2 (TXA2) produced by platelets, which took place several years later, gave rise to the era of using small "cardiac" doses of ASA in cardiovascular diseases [9]. In addition to the well-researched antiplatelet effect, new non-COX-1 dependent mechanisms of action have been discovered, e.g., the impact of ASA on endothelial function, whose role in the pathogenesis of hypertension and its complications turns out to be very significant. Properly functioning endothelium enables vasodilatation as well as inhibits inflammation, platelet aggregation and adhesion, and proliferation of vascular smooth muscle cells. The mechanism of action of ASA by inhibition of cyclooxygenase (COX) results in the suppression of thromboxane production, thus reducing platelet aggregation and increasing the secretion of prostacyclins, which have an opposite effect to thromboxane. ASA also increases the activation of nitric oxide synthetase and production of platelet NO. Endothelial damage and dysfunction are observed in diabetes, atherosclerosis, hypertension, hyperlipidemia, and nicotinism. Magen et al. confirmed the beneficial effect of ASA on endothelium in a study conducted on 21 patients with hypertension and hypercholesterolemia. The study showed that the addition of $100 \mathrm{mg}$ of aspirin to hypotensive and hypolipidemic therapy reduces systolic and diastolic pressure and improves endothelial function [18].

Because of the antiplatelet properties of ASA, the drug has been used in the secondary prevention of cardiovascular diseases; the use of ASA in primary prevention is currently under discussion, but the range of indications has not been established yet. Over the years studies have also been conducted on the hypotensive effect of acetylsalicylic acid (ASA). Hermida et al. carried out years of research on the chronotherapy of aspirin administered in small "cardiac" doses to lower pressure in various groups of patients. One study was conducted on a population of patients with mild, untreated hypertension. The patients were divided into three control groups. Only the group that received $100 \mathrm{mg}$ of aspirin in the evening exhibited a decrease in systolic and diastolic pressure by $6 / 4 \mathrm{~mm} \mathrm{Hg}$ when compared with the group which received aspirin in the morning [19]. In another study that they conducted acetylsalicylic acid administered in the evening at a dose of $100 \mathrm{mg}$ reduced blood pressure by $7 / 5 \mathrm{~mm} \mathrm{Hg}$. Such an effect was not observed in the group receiving ASA in the morning, where blood pressure increased by $2.6 / 1.6 \mathrm{~mm} \mathrm{Hg}$ [20]. Higher doses of ASA $(500 \mathrm{mg}$ ) resulted in a pressor effect, even when administered in the evening.

In their studies of 2005, Hermida et al. examined 257 patients with mild hypertension, non-dippers and dippers, divided into groups receiving $100 \mathrm{mg}$ of Aspirin in the morning or evening. Aspirin, as an antioxidative agent affecting the production of nitric oxide released from vascular endothelium, prevents hypertension induced by angiotensin II. After 3 months of the study, a significant reduction in blood pressure was observed with evening administration of as- 
pirin, especially in dippers $(11.0 / 7.1 \mathrm{~mm} \mathrm{Hg})$ as compared to non-dippers (5.5/3.3 $\mathrm{mm} \mathrm{Hg})$ [21].

Gender differences have also been taken into account in studies on aspirin chronotherapy. In 2010 Ayal and Hermida demonstrated temporal differences in the administration of aspirin in men and women. Previous studies had already shown differences in the regulation of blood pressure, pathophysiology of hypertension, and response to antihypertensive drugs in both sexes. The study included 130 men and 186 women with mild, untreated hypertension. During the study $100 \mathrm{mg}$ of aspirin was administered in the morning and in the evening. In men the morning administration had no effect, while the evening administration reduced blood pressure. In women the morning administration of aspirin increased blood pressure, while the evening administration had a hypotensive effect which was stronger than in men. Thus, evening administration of aspirin reduces blood pressure in both women and men, but better blood pressure control and vascular protection is achieved in women [22].

Ayala et al. conducted research on the chronotherapy of aspirin in pregnant women. They described the hypotensive effect of aspirin in small doses administered to pregnant women; the drug was introduced after 12-16 weeks of pregnancy. Evening administration of aspirin showed a hypotensive effect and prevented complications associated with hypertension. The hypotensive effect was greater for higher risks of complications. The study included 350 pregnant women with a high risk of complications divided into 6 groups. Blood pressure was controlled by means of Holter ABPM examination. The influence of aspirin on blood pressure was dependent on the time of administration. After waking up there was no effect when compared with the placebo group. A significant effect occurred when aspirin was administered $8 \mathrm{~h}$ after waking up, and the best results were noted after evening administration of the drug. Women receiving low doses of aspirin in the evening, when compared with the placebo group, exhibited fewer adverse events, such as: preeclampsia, intrauterine growth restriction, miscarriage, premature labor [23]. In previous studies conducted in 1997, 1999, and 2003, Hermida et al. described the hypotensive effect of aspirin in pregnant women; the drug was introduced after 12-16 weeks of pregnancy in small doses. Evening administration of aspirin showed a hypotensive effect and prevented complications associated with hypertension. The hypotensive effect was greater for higher risks of complications [24-26].

In 2014 Bonten et al. investigated the effect of aspirin with morning and evening administration and its impact on the morning increase in platelet activity, which is associated with a higher risk of cardiovascular events. The study included healthy volunteers who received aspirin at a dose of $80 \mathrm{mg}$ in the morning or evening in 2 two-week periods and a month-long break. At the end of each period COX-1 dependent (VerifyNow Aspirin) and non-COX-1 dependent (flow cytometry) platelet function was measured. It was demonstrated that a small dose of aspirin administered in the evening reduces COX-1 dependent platelet function in the morning hours in healthy individuals [27].

In 2015 Bonten et al. evaluated the effect of ASA administered in the morning and evening on blood pressure and platelet activity in 290 patients treated for cardiovascular disease. It confirms the beneficial anti-aggregation effect of ASA with evening administration when compared with administration in the morning hours. It did not, however, show any effect of ASA on the reduction of arterial blood pressure [28].

In my opinion acetylsalicylic acid may be considered one of the greatest pharmacotherapeutic achievements in the history of medicine. The gradually discovered multitude of applications of ASA is truly amazing - from traditional analgesic and anti-inflammatory, through preventive and cardiological, to the less documented hypotensive effects. There are studies that also discuss the use of ASA in pregnant women with a high cardiac risk, demonstrating a reduction in adverse events, such as premature birth, miscarriage, or preeclampsia.

Recent studies suggest that a low dose of aspirin administered in the evening reduces COX-1 dependent platelet function in the morning in healthy patients. Future research with larger study groups is necessary to answer the question of whether ASA administered in the evening reduces the risk of cardiovascular events in the morning hours.

\section{Disclosure}

Authors report no conflict of interest.

\section{References}

1. Smolensky MH. Chronobiology and chronotherapeutics. Applications to cardiovascular medicine. Am J Hypertens 1996; 9: 11S-21S.

2. Andrys-Wawrzyniak I, Jabłecka A. Chronobiologia, chronofarmakologia i ich miejsce w medycynie. Farm Współczesna 2008; 1: 156-168.

3. Gnecchi-Ruscone T, Piccaluga E, Guzzetti S, Contini M, Montano N, Nicolis E. Morning and monday: critical periods for the onset of acute myocardial infarction. The GISSI 2 Study experience. Eur Heart J 1994; 15: 882-887.

4. Ohlson CG, Bodin L, Bryngelsson IL, Helsing M, Malmberg L. Winter weather conditions and myocardial infarctions. Scand J Soc Med 1991; 19: 20-25.

5. Portaluppi F, Hermida RC. Circadian rhythms in cardiac arrhythmias and opportunities for their chronotherapy. Adv Drug Deliv Rev 2007; 59: 940-951.

6. White WB. Circadian variation of blood pressure: clinical relevance and implications for cardiovascular chronotherapeutics. Blood Press Monit 1997; 2: 47-51.

7. Pickering TG. The clinical significance of diurnal blood pressure variations. Dippers and nondippers. Circulation 1990; 81: 700-702.

8. Uzu T, Ishikawa K, Fujii T, Nakamura S, Inenaga T, Kimura G. Sodium restriction shifts circadian rhythm of blood pressure from nondipper to dipper in essential hypertension. Circulation 1997; 96: 1859-1862.

9. Tykarski A, Kostka-Jeziorny K, Kawecka-Jaszcz K. Chronoterapia nadciśnienia tętniczego. Arter Hypertens 2006; 10: 235-250.

10. Marciniak A, Grześk G, Koziński M, Grześk E, Kubica J. Zmienność dobowa w układzie hemostazy. Folia Cardiol 2010; 5: 1-7.

11. Kapiotis S, Jilma B, Quehenberger P, Ruzicka K, Handler S, Speiser W. Morning hypercoagulability and hypofibrinolysis. Diurnal variations in circulating activated factor VII, prothrombin fragment F1+2, and plasmin-plasmin inhibitor complex. Circulation 1997; 96: 19-21.

12. Herold M, Cornélissen G, Loeckinger A, Koeberle D, Koenig P, Halberg F. About 8-hour variation of circulating human endothelin-1. Peptides 1998; 19: 821-825. 
13. Jaffe EA. Cell biology of endothelial cells. Hum Pathol 1987; 18: 234-239.

14. Haus E. Chronobiology of hemostasis and inferences for the chronotherapy of coagulation disorders and thrombosis prevention. Adv Drug Deliv Rev 2007; 59: 966-984.

15. Ehrly AM, Jung G. Circadian rhythm of human blood viscosity. Biorheology 1973; 10: 577-583.

16. Undar L, Türkay C, Korkmaz L. Circadian variation in circulating platelet aggregates. Ann Med 1989; 21: 429-433.

17. Undar L, Ertuğrul C, Altunbaş $H$, Akça $S$. Circadian variations in natural coagulation inhibitors protein $\mathrm{C}$, protein $\mathrm{S}$ and antithrombin in healthy men: a possible association with interleukin-6. Thromb Haemost 1999; 81: 571-575.

18. Magen E, Viskoper JR, Mishal J, Priluk R, London D, Yosefy C. Effects of lowdose aspirin on blood pressure and endothelial function of treated hypertensive hypercholesterolaemic subjects. J Hum Hypertens 2005; 19: 667-673.

19. Hermida RC, Ayala DE, Mojón A, Fernández JR. Ambulatory blood pressure control with bedtime aspirin administration in subjects with prehypertension. Am J Hypertens 2009; 22: 896-903.

20. Hermida RC, Ayala DE, Calvo C, López JE. Aspirin administered at bedtime, but not on awakening, has an effect on ambulatory blood pressure in hypertensive patients. J Am Coll Cardiol 2005; 46: 975-983.

21. Hermida RC, Ayala DE, Calvo C, López JE, Mojón A, Rodríguez M, Fernández JR. Differing administration time-dependent effects of aspirin on blood pressure in dipper and non-dipper hypertensives. Hypertens Dallas Tex 1979 2005; 46: 1060-1068.
22. Ayala DE, Hermida RC. Sex differences in the administration-time-dependent effects of low-dose aspirin on ambulatory blood pressure in hypertensive subjects. Chronobiol Int 2010; 27: 345-362.

23. Ayala DE, Ucieda R, Hermida RC. Chronotherapy with low-dose aspirin for prevention of complications in pregnancy. Chronobiol Int 2013; 30: 260-279.

24. Hermida RC, Ayala DE, Iglesias M, Mojón A, Silva I, Ucieda R, Fernandez JR. Time-dependent effects of low-dose aspirin administration on blood pressure in pregnant women. Hypertens Dallas Tex 1979 1997; 30: 589-595.

25. Hermida RC, Ayala DE, Fernández JR, Mojón A, Alonso I, Silva I, Ucieda R, Codesido J, Iglesias M. Administration time-dependent effects of aspirin in women at differing risk for preeclampsia. Hypertens Dallas Tex 1979 1999; 34: 1016-1023.

26. Hermida RC, Ayala DE, Iglesias M. Administration time-dependent influence of aspirin on blood pressure in pregnant women. Hypertens Dallas Tex 1979 2003; 41: 651-656.

27. Bonten TN, Saris A, van Oostrom MJ, Snoep JD, Rosendaal FR, Zwaginga J, Eikenboom J, van der Meer PF, van der Bom JG. Effect of aspirin intake at bedtime versus on awakening on circadian rhythm of platelet reactivity. A randomised cross-over trial. Thromb Haemost 2014; 112: 1209-1218.

28. Bonten TN, Snoep JD, Assendelft WJJ, Zwaginga JJ, Eikenboom J, Huisman MV, Rosendaal FR, van der Bom JG. Time-dependent effects of aspirin on blood pressure and morning platelet reactivity: a randomized cross-over trial. Hypertens Dallas Tex 1979 2015; 65: 743-750. 